Research note

\title{
New eastern Pacific Ocean record of the rare deep-water fish, Psychrolutes phrictus (Scorpaeniformes: Psychrolutidae)
}

\author{
Registro nuevo en el océano Pacífico oriental de un pez raro de profundidad, Psychrolutes phrictus \\ (Scorpaeniformes: Psychrolutidae) \\ Hugo Aguirre-Villaseñor ${ }^{\mathrm{a}, *}$, Edgar Cruz-Acevedo $^{\mathrm{b}}{ }$, Carolina Salas-Singh ${ }^{\mathrm{c}}$ \\ ${ }^{a}$ Centro Regional de Investigación Pesquera-Mazatlán, Instituto Nacional de Pesca, Calzada Sábalo-Cerritos s/n, Apartado postal 1177,82112 Mazatlán, \\ Sinaloa, Mexico \\ b Programa de Doctorado en Ciencias, Centro de Investigación en Alimentación y Desarrollo, A.C., Avenida Sábalo-Cerritos, s/n, 82100 Mazatlán, Sinaloa, Mexico \\ ${ }^{\mathrm{c}}$ Posgrado en Ciencias del Mar y Limnología, Unidad Académica Mazatlán, Universidad Nacional Autónoma de México, Av. Joel Montes Camarena s/n, \\ Apartado postal 811, 82040 Mazatlán, Sinaloa, Mexico
}

Received 26 October 2015; accepted 14 March 2016

Available online 6 August 2016

\begin{abstract}
Psychrolutes phrictus is a benthic deep sea fish known from the eastern North Pacific. On 30 March 2008, a specimen of the blob sculpin $P$. phrictus (297 mm LT) was caught off the Guerrero coast, Mexico $\left(17^{\circ} 45^{\prime} 24^{\prime \prime} \mathrm{N}, 101^{\circ} 59^{\prime} 04^{\prime \prime} \mathrm{W}\right)$. The blob sculpin was taken at a depth of $1,100 \mathrm{~m}$ within a temperature range of $3.88-4.25^{\circ} \mathrm{C}$, where hypoxic $(0.57-0.39 \mathrm{mg} / \mathrm{l})$ conditions prevailed; the specimen was captured over a muddy bottom using a benthic sledge. Representatives of this species had never been reported off the Mexican Pacific coast; our new record extends the known southernmost range by $1,733 \mathrm{~km}$, from $33^{\circ} 19^{\prime} \mathrm{N}$ to $17^{\circ} 45^{\prime} \mathrm{N}$ for the American coast. Although high variations in morphometric and meristic values are known for the 4 species of the genus Psychrolutes (P. paradoxus, P. phrictus, P. sigalutes, and P. sio) from the eastern Pacific Ocean, a combination of traits and species distribution allow us to identity this specimen as $P$. phrictus.

All Rights Reserved @ 2016 Universidad Nacional Autónoma de México, Instituto de Biología. This is an open access item distributed under the Creative Commons CC License BY-NC-ND 4.0.
\end{abstract}

Keywords: Blob sculpin; Benthic; Mexican Pacific coast; Hypoxic conditions; Morphometrics; Meristics

\section{Resumen}

Psychrolutes phrictus es un pez bentónico de profundidad, que se distribuye en el Pacífico Norte. El 30 de marzo de 2008 se capturó un espécimen

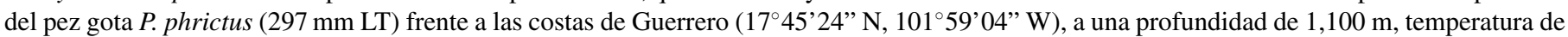
3.88 a $4.25^{\circ} \mathrm{C}$, donde las condiciones de hipoxia prevalecen $(0.57-0.39 \mathrm{mg} / \mathrm{l})$; el arrastre se realizó con un patín béntico sobre un fondo fangoso. A la fecha no se había documentado ningún ejemplar de esta especie en las costas de México, por lo que este nuevo registro extiende el intervalo más sureño de distribución $1,733 \mathrm{~km}$ de $33^{\circ} 19^{\prime} \mathrm{N}$ a $17^{\circ} 45^{\prime} \mathrm{N}$ para la costa americana. Aun cuando las variaciones merísticas y morfológicas son grandes en las 4 especies del género Psychrolutes ( $P$. paradoxus, $P$. phrictus, $P$. sigalutes y $P$. sio) en el océano Pacífico oriental, una combinación de caracteres y de su distribución permiten determinar el espécimen en cuestión como $P$. phrictus.

Derechos Reservados (C) 2016 Universidad Nacional Autónoma de México, Instituto de Biología. Este es un artículo de acceso abierto distribuido bajo los términos de la Licencia Creative Commons CC BY-NC-ND 4.0.

Palabras clave: Pez gota; Bentónico; Costa pacífica mexicana; Hipoxia; Morfometría; Merística

\footnotetext{
* Corresponding author.

E-mail address: hugo.aguirre @inapesca.gob.mx (H. Aguirre-Villaseñor). México.
}

The family Psychrolutidae Günther, 1861 is characterised by having large heads and bodies that taper back into small, flat tails, a spinous dorsal fin buried in loose skin and flesh (Jordan \& Gilbert, 1882), a suborbital stay, pseudobranchiae, pelvic fins of thoracic position, 3 and a half gill arches, naked skin (Günther, 
Table 1

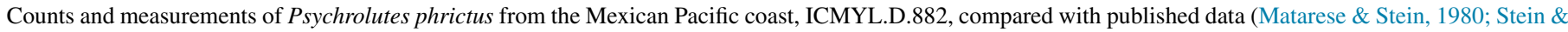

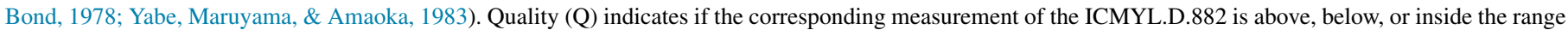
reported in the literature. Morphometric measurements as a percentage of standard length (\% SL) and head length (\% HL).

\begin{tabular}{|c|c|c|c|c|c|c|c|c|}
\hline \multirow[t]{2}{*}{ Counts } & & \multicolumn{2}{|l|}{ ICMYL.D.882 } & \multicolumn{3}{|c|}{ Literature } & & \multirow[t]{2}{*}{ Q } \\
\hline & & & & Min & & $\operatorname{Max}$ & & \\
\hline Dorsal fin spines & & VIII & & VII & & VIII & & Inside \\
\hline Anal fin rays & & 13 & & 12 & & 14 & & Inside \\
\hline Pectoral fin rays & & 21 & & 22 & & 26 & & Below \\
\hline Pelvic fin rays & & $\mathrm{I}, 3$ & & $\mathrm{I}, 3$ & & $\mathrm{I}, 3$ & & Inside \\
\hline Caudal fin rays & & 13 & & 13 & & 13 & & Inside \\
\hline Gill rakers first arch & & $7+2$ & & 9 & & 13 & & Inside \\
\hline Vertebrae & & 33 & & 33 & & 36 & & Inside \\
\hline Abdominal & & 12 & & 12 & & 13 & & Inside \\
\hline Caudal & & 21 & & 21 & & 24 & & Inside \\
\hline Character & $\mathrm{mm}$ & $(\% \mathrm{SL})$ & $(\% \mathrm{HL})$ & $(\% \mathrm{SL})$ & Q & & $(\% \mathrm{HL})$ & $\mathrm{Q}$ \\
\hline Total length & 297 & & & & & & & \\
\hline Standard length & 222 & & & & & & & \\
\hline Measurements & & & & & & & & \\
\hline Predorsal length & 108.3 & 49 & 98 & & & & & \\
\hline Snout-anus length & 144 & 65 & 131 & & & & $93.8-132.2$ & Inside \\
\hline Prepectoral length & 73 & 33 & 66 & & & & & \\
\hline Prepelvic length & 87 & 39 & 79 & & & & & \\
\hline Pectoral fin length & 59 & 27 & 54 & & & & $44.9-62.3$ & Inside \\
\hline Pectoral fin spine length & 29 & 13 & 26 & & & & & \\
\hline Pelvic fin length & 27 & 12 & 25 & & & & & \\
\hline Pelvic fin spine length & & & & & & & & \\
\hline Pectoral base & 48 & 22 & 44 & & & & & \\
\hline Dorsal fin length & 120 & 54 & 109 & & & & & \\
\hline Caudal fin length & 75 & 34 & 68 & & & & & \\
\hline Caudal peduncle length & 17 & 8 & 15 & & & & & \\
\hline Caudal peduncle depth & 19 & 9 & 17 & $6.7-8.3$ & Above & & & \\
\hline Head height (Body depth) & 80 & 36 & 73 & $23.3-34.5$ & Above & & & \\
\hline Head length & 110 & 50 & 100 & $41-60.6$ & Inside & & & \\
\hline Heath width & 126 & 57 & 115 & & & & & \\
\hline Snout length & 34 & 15 & 31 & $13.3-14.3$ & Above & & $30.3-35.7$ & Inside \\
\hline Eye diameter (horizontal) & 11 & 5 & 10 & & & & $7.9-13$ & Inside \\
\hline Eye diameter (vertical) & 8 & 4 & 7 & & & & & \\
\hline Interorbital space & 52 & 23 & 47 & & & & $33.2-47.6$ & Inside \\
\hline Internostril space & 37 & 17 & 34 & & & & & \\
\hline Superior jaw length & 27 & 12 & 25 & & & & & \\
\hline Inferior jaw length & 21 & 9 & 19 & & & & & \\
\hline
\end{tabular}

1861), and 7 branchiostegal rays (Yabe, 1984). In the eastern Pacific Ocean, 4 species of the genus Psychrolutes have been reported: Psychrolutes paradoxus Günther, 1861 occurs from the North Pacific to northern Bering Sea (Eschmeyer \& Fong, 2015). Psychrolutes phrictus Stein and Bond, 1978 occurs between California and the northern Bering Sea (Stein \& Bond, 1978); Psychrolutes sigalutes (Jordan \& Starks, 1895) from the Bering Sea to eastern North Pacific (Eschmeyer \& Fong, 2015); and Psychrolutes sio Nelson, 1980 from northernmost Peru to central Chile (Nelson, Chirichigno, \& Balbontin, 1985). Confirmation of the taxonomic identity of this specimen was made by comparison of the meristic and morphometric characters reported for the 4 species from the eastern Pacific Ocean (Tables 1 and 2).

Representatives of $P$. phrictus have never been reported off the Mexican Pacific coast; thus our new record extends the known southernmost range $1,733 \mathrm{~km}$ from $33^{\circ} 19^{\prime} \mathrm{N}$ (LACM, 2015) to $17^{\circ} 45^{\prime} \mathrm{N}$ off the western American coast (Fig. 1). The blob sculpin was collected on 30 March 2008 using a benthic sledge at a depth range of 1,100-1,199 $\mathrm{m}$ and a water temperature range of $3.88-4.25^{\circ} \mathrm{C}$, where hypoxic $(0.57-0.39 \mathrm{mg} / \mathrm{l})$ conditions prevailed, during the oceanographic cruise Talud XII, Sta. 13 south-east of Petacalco, Guerrero, México $\left(17^{\circ} 45^{\prime} 24^{\prime \prime} \mathrm{N}\right.$, $\left.101^{\circ} 59^{\prime} 04^{\prime \prime} \mathrm{W}\right)$. The specimen was collected by the R.V. El Puma of the Universidad Nacional Autónoma de México. Because of the uniqueness of this specimen, it was fixed in $10 \%$ formalin and later preserved in $70 \%$ ethanol. The specimen was deposited in the reference collection (fishes) of the Instituto de Ciencias del Mar y Limnología, Unidad Académica Mazatlán, with the catalogue number ICMYL.D.882.

Measurements and counts follow Nelson (1982). Electron tomography was taken to enable the count of vertebrae and facilitate the examination of branchiostegal rays, using a Toshiba Multislice CT. Axial, sagittal, and coronal reformatting and $3 \mathrm{D}$ reconstructions (slice interval: $0.6 \mathrm{~mm}$ ) were performed on 


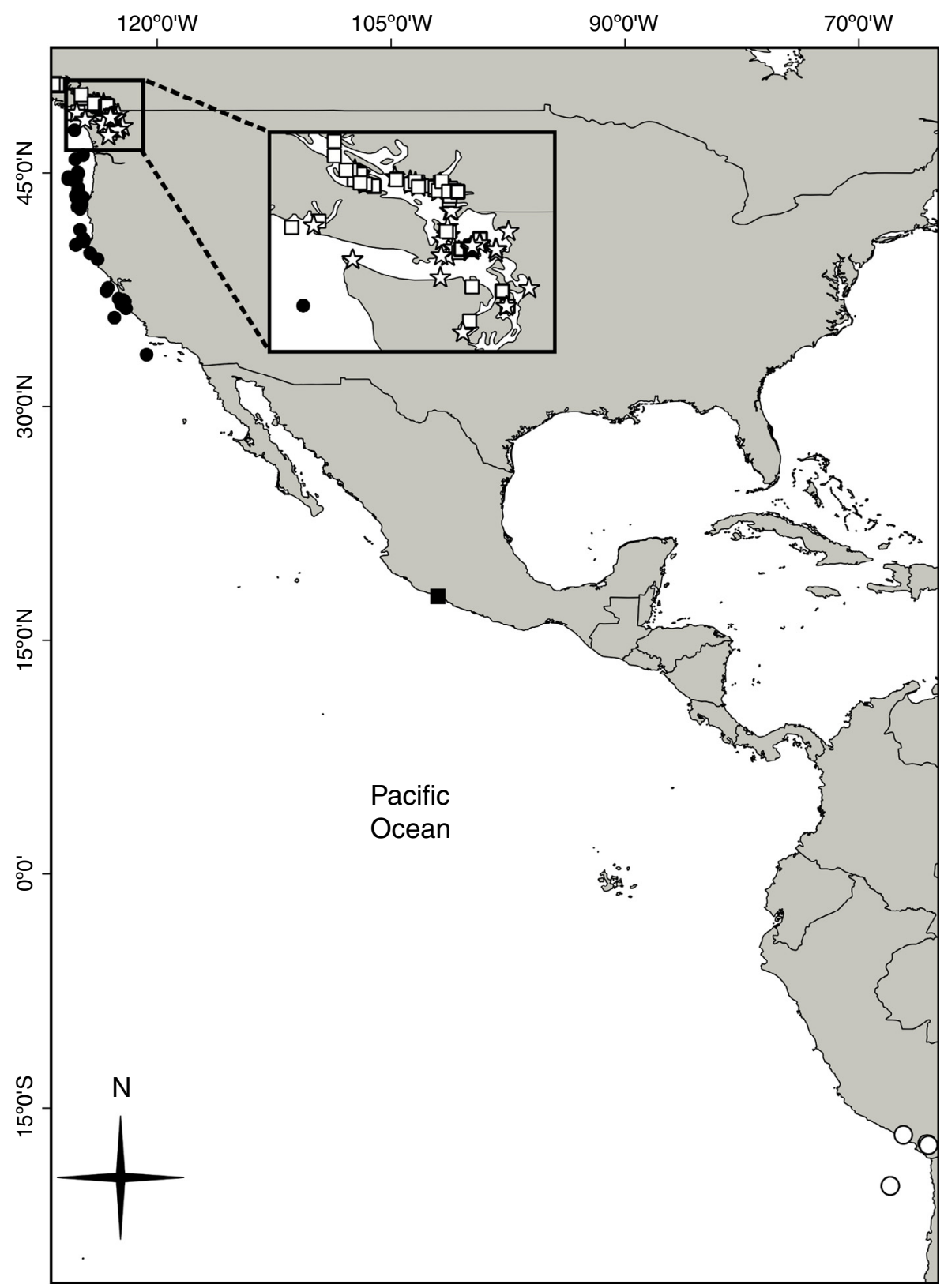

Figure 1. Distribution map of Psychrolutes species reported in the eastern Pacific Ocean: P. paradoxus (open star), P. phrictus (black circle), P. sigalutes (open square), $P$. sio (open circle) and new P. phrictus record ICMYL.D.882 (black square).

Sources: Eschmeyer and Fong (2015), LACM (2015), Matarese and Stein (1980), Nelson et al. (1985), Stein and Bond (1978).

Osirix 6.5. All measurements were performed 2 months after the preservation of the specimen. Lateral line pores were counted using a dissecting microscope. A distribution map was created using QGIS 2.10, and the figure was prepared with Inkscape 0.48 .

The colour of the specimen before preservation was greyish brown above and below, with mottling sometimes present, especially on the ventral area; fins darker than body, margin of rays lighter than fins. The peritoneum was pale (Fig. 2). After preservation, the body colouration was uniformly brownish, paler on the ventral face, mottling not as evident as before preservation; fins darker than body, margin of rays lighter than fins. The lateral-line pore count was incomplete because portions of skin were lost in some areas of the body, although 4 pores were observed. The diameters of the anteriormost lateral line pores were smaller than those of posteriormost position; diameter increased gradually towards the caudal area.

The morphological characters of the specimen examined here are concordant with those described for $P$. phrictus and data available in the literature (Table 1). However, our specimen has a deeper head (38\% SL vs. $23.3-34.5 \%$ SL) and a higher caudal peduncle depth (9\% SL vs. 6.7-8.3\% SL). These differences are minimal and could be associated with the allometry by age, size, or sex of the specimens, even a limited sample size for description of the variation of these characters; also, morphometric variations among the members of the family Psychrolutidae 
Table 2

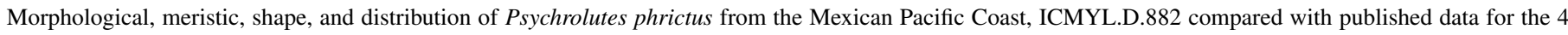

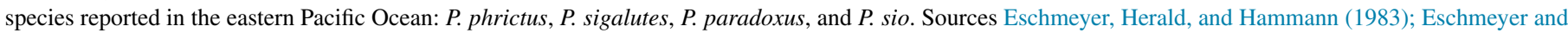

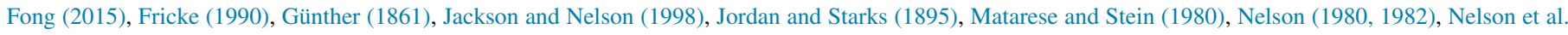
(1985), Stein and Bond (1978), Yabe et al. (1983).

\begin{tabular}{|c|c|c|c|c|c|}
\hline Attribute & ICMYL.D.882 & P. phrictus & P. sigalutes & P. paradoxus & P. sio \\
\hline Head length \%SL & 50 & $41.1-60.6$ & 33 & $40.2-44.4$ & $40.8-45.9$ \\
\hline Jaws & Upper jaw protruding & Upper jaw protruding & Lower jaw protruding & Jaws nearly equal & Jaws nearly equal \\
\hline Dorsal fin rays & VIII, 17 & VII-IX, 19-20 & VII-VIII, 16-19 & IX-XII, 12-17 & VII-VIII, 16-18 \\
\hline Pectoral fin rays & 21 & $22-26$ & 14-18 & $19-23$ & $21-22$ \\
\hline Anal fin rays & 13 & 13 & $12-15$ & $10-14$ & $13-14$ \\
\hline Anus & $\begin{array}{l}\text { Between anal fin and } \\
\text { pelvic fin }\end{array}$ & $\begin{array}{l}\text { Between anal fin and } \\
\text { pelvic fin }\end{array}$ & $\begin{array}{l}\text { Immediately in front } \\
\text { of anal fin }\end{array}$ & $\begin{array}{l}\text { Between anal fin and } \\
\text { pelvic fin }\end{array}$ & $\begin{array}{l}\text { Between anal fin and } \\
\text { pelvic fin }\end{array}$ \\
\hline Gill rakers & $7+2$ & $9-13$ & 7 & & \\
\hline Vertebrae & 33 & $33-35$ & $33-35$ & $34-37$ & $32-34$ \\
\hline Pectoral fin length $\% \mathrm{HL}$ & 54 & $44.9-62.3$ & 120 & 92.6 & $56.5-65.2$ \\
\hline Pectoral fin extending & $\begin{array}{l}\text { To first third of anal } \\
\text { fin }\end{array}$ & $\begin{array}{l}\text { To first third of anal } \\
\text { fin }\end{array}$ & To half of anal fin & To half of anal fin & $\begin{array}{l}\text { To first third of anal } \\
\text { fin }\end{array}$ \\
\hline Maximum SL & $222 \mathrm{~mm}$ & $560 \mathrm{~mm}$ & $83 \mathrm{~mm}$ & $58 \mathrm{~mm}$ & $345 \mathrm{~mm}$ \\
\hline Depth range $(\mathrm{m})$ & 1,100 & $660-2,800$ & $0-225$ & $0-220$ & $700-1,200$ \\
\hline Distribution in the eastern & Central Mexican & From Alaska to & From Alaska to & From Alaska to & From Peru to Chile \\
\hline Pacific Ocean & Pacific & California & Washington & Washington & \\
\hline Peritoneum & Pale & Pale & Blackish & Blackish & Blackish \\
\hline Colour & $\begin{array}{l}\text { Relatively uniform, } \\
\text { grey-brown, mottling } \\
\text { sometimes present } \\
\text { (especially on ventral } \\
\text { area) }\end{array}$ & $\begin{array}{l}\text { Relatively uniform, } \\
\text { greyish or blackish, } \\
\text { mottling sometimes } \\
\text { present (especially on } \\
\text { head), ventral surface } \\
\text { often white }\end{array}$ & Relatively uniform & $\begin{array}{l}\text { Brownish-grey, with } \\
\text { large deep-brown } \\
\text { blotches; caudal and } \\
\text { pectoral fins dotted } \\
\text { and spotted with black }\end{array}$ & $\begin{array}{l}\text { Relatively uniform } \\
\text { (no distinct banding } \\
\text { or spotted pattern }\end{array}$ \\
\hline
\end{tabular}

are great, probably because of the easily distortable nature of their bodies during or subsequent to capture (Jackson \& Nelson, 2006; Stein \& Bond, 1978).

Meristically, differences were found in the count of dorsal fin rays in our specimen when compared with that reported in literature (17 vs. 19-20) and pectoral fin rays (21 vs. 22-26) (Table 1). For the 4 species of Psychrolutes reported in the Eastern Pacific, variations were observed in the count of dorsal fin rays: P. paradoxus (12-17), P. sigalutes (16-19), P. sio (16-18), and $P$. phrictus (19-20); in the case of the number of pectoral fin rays, it was lower in $P$. sio (21-22), P. paradoxus (19-23), and $P$. sigalutes (14-18) than in P. phrictus (22-26) (Table 2).

Within the family Psychrolutidae, Byrkjedal, HadlerJacobsen, Rees, and Orlov (2014) evaluated the variation in

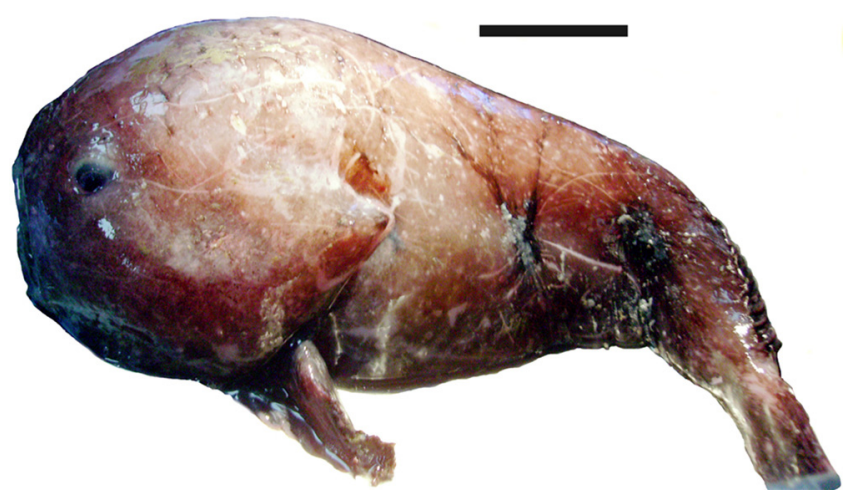

Figure 2. Left side of Psychrolutes phrictus before preservation ICMYL.D.882, bar $=50 \mathrm{~mm}$. descriptive taxonomic characters of 3 species of the genus Cottunculus and found 5 diagnostic characters to vary geographically (east-west). Three showed a significant correlation with the depth of capture.

The specimen of $P$. phrictus reported here is distinguished from other members of the genus ( $P$. paradoxus, $P$. sigalutes, and $P$. sio) by differences in the head length as a proportion of SL and relative pectoral fin length as a proportion of $\mathrm{HL}$; from $P$. paradoxus by pectoral fin rays extending to half of the anal fin, jaws nearly equal anteriorly, maximum SL $58 \mathrm{~mm}$, distribution northeastern Pacific Ocean from Alaska to Washington, depth range $0-220 \mathrm{~m}$, and colour pattern; also $P$. phrictus differs from $P$. sigalutes by its pectoral fin rays extending to half of the anal fin, lower jaw protruding slightly beyond upper jaw, maximum SL $83 \mathrm{~mm}$, anus immediately in front of anal fin, with a distribution range in the northeastern Pacific Ocean from Alaska to Washington, depth range $0-225 \mathrm{~m}$, and colour pattern; finally, $P$. phrictus is discriminated from $P$. sio by having jaws nearly equal anteriorly, a distribution range in the southeastern Pacific from Peru to Chile, a depth range 700-1,200 m, colour pattern, and dark peritoneum (Table 2).

The authors thank Cynthia Klepadlo for comments on an early draft of the manuscript, Michel Hendrickx director of the Talud project, Felipe Amezcua curator of fishes at the collection of the Instituto de Ciencias del Mar y Limnología, Unidad Académica Mazatlán, Francisco Gavito and Pedro Gavito for their help with the tomographic reconstruction of 3D images, and the academic staff, students, and crew of the R.V. El Puma, who participated in the Talud cruises. Ship time was provided 
by the Coordinación de la Investigación Científica, UNAM. Tomography was supported by the Conacyt project 179467 . Two anonymous reviewers made useful comments on the manuscript that improved the content and clarity of the information.

\section{Appendix A. Supplementary data}

Supplementary data associated with this article can be found, in the online version, at doi:10.1016/j.rmb.2016.06.013.

\section{References}

Byrkjedal, I., Hadler-Jacobsen, S., Rees, D., \& Orlov, A. (2014). Molecular and morphological variation in saddled fathead sculpins (Psychrolutidae: Cottunculus) of the north-east Atlantic Ocean, with a synonymy of three species. Journal of Fish Biology, 85, 821-837.

Eschmeyer, W. N., \& Fong, J. D. (2015). Catalog of fishes. California Academy of Sciences. Retrieved on October 4th, 2015 from: http://researcharchive. calacademy.org/research/ichthyology/catalog/SpeciesByFamily.asp

Eschmeyer, W. N., Herald, E. S., \& Hammann, H. (1983). A field guide to Pacific coast fishes of North America. Boston: Houghton Mifflin Company.

Fricke, R. (1990). A new species of psychrolutid fish from Western Australia. Japanese Journal of Ichthyology, 36, 404-409.

Günther, A. (1861). . Catalogue of the acanthopterygian fishes in the collection of the British Museum (Vol. 3) London: Taylor and Francis.

Jackson, K. L., \& Nelson, J. S. (1998). Ambophthalmos, a new genus for "Neophrynichthys" angustus and "Neophrynichthys" magnicirrus, and the systematic interrelationships of the fathead sculpins (Cottoidei, Psychrolutidae). Canadian Journal of Zoology, 76, 1344-1357.
Jackson, K. L., \& Nelson, J. S. (2006). Ebinania australiae, a new species of fathead sculpin from southern Australia (Scorpaeniformes: Psychrolutidae). Records of the Australian Museum, 58, 37-42.

Jordan, D. S., \& Gilbert, C. H. (1882). Synopsis of the fishes of North America. Washington: Government Printing Office.

Jordan, D. S., \& Starks, E. C. (1895). The fishes of Puget Sound. Proceedings of the California Academy of Sciences (Ser. 2), 5, 785-855.

LACM. (2015). Fish collection at Natural History Museum of Los Angeles County. Retrieved on October 4th, 2015 from: http://portal.vertnet.org/ $\mathrm{o} / \mathrm{lacm} / \mathrm{fish}$ ?id=38675-001

Matarese, A. C., \& Stein, D. L. (1980). Additional records of the sculpin Psychrolutes phrictus in the eastern Bering Sea and off Oregon. Fishery Bulletin, $78,169-171$.

Nelson, J. S. (1980). Psychrolutes sio, a new psychrolutid fish (Scorpaeniformes) from the southeastern Pacific. Canadian Journal of Zoology, 58, 443-449.

Nelson, J. S. (1982). Two new South Pacific fishes of the genus Ebinania and contributions to the systematics of Psychrolutidae (Scorpaeniformes). Canadian Journal of Zoology, 60, 1470-1504.

Nelson, J. S., Chirichigno, N., \& Balbontin, F. (1985). New material of Psychrolutes sio (Scorpaeniformes, Psychrolutidae) from the eastern Pacific of South America and comments on the taxonomy of Psychrolutes intermis and Psychrolutes macrocephalus from the eastern Atlantic of Africa. Canadian Journal of Zoology, 63, 444-451.

Stein, D. L., \& Bond, C. E. (1978). A new deep-sea fish from the eastern North Pacific Psychrolutes phrictus (Pisces: Cottidae [Psychrolutinae]). Contributions in Science (Los Angeles County Museum), 296, 1-9.

Yabe, M. (1984). Comparative osteology and myology of the superfamily Cottoidea (Pisces: Scorpaeniformes) and its phylogenetic classification Ph.D. Thesis. Japan: Faculty of Fisheries, Hokkaido University.

Yabe, M., Maruyama, S., \& Amaoka, K. (1983). First record of 5 cottid fishes and a psychrolutid fish from Japan. Japanese Journal of Ichthyology, 29, 456-464. 